\title{
SELF-REGULATORY SYSTEMS: SELF-REGULATION AND LEARNING
}

\author{
Maja Matric \\ University of Maribor, Faculty of Education, Slovenia \\ maja.matric@gmail.com
}

\section{Professional Paper \\ doi:10.5937/jouproman6-19338}

\begin{abstract}
Self-regulation provides individuals the necessary means to achieve goals which can either arise from their own interests or societal demands. In both cases, achieving goals will enable individuals to experience self-fulfilment and success. Self-regulatory systems also maintain our actions within the limits of acceptable as well as restrain from unwanted behaviours.

Self-regulatory learning helps learners achieve higher academic goals as it gives students control over their learning. In order to successfully selfregulate one's learning, it is important to recognize the essential components of self-regulatory learning, which help chose learning methods and strategies. We aimed at discovering which learning strategies and styles the students prefer and which elements of self-regulatory learning occur in the learning process. We can conclude that the students lack the knowledge of self-regulatory processes and learning strategies, and are unaware of their preferred learning styles.
\end{abstract}

Key words: self-regulation, learning, learning styles, motivation

\section{Introduction}

Self-regulation is described as the individuals' ability to direct their actions towards goals and ideals which can come from personal desires or the expectations of others, and helps individuals adjust to the demands of society and the environment. Zimmerman (2000) believes self-regulation is of great importance for the existence of mankind because it is directly linked to being socially accepted and depending on the group, as humans tend to get most of what we need from other humans. Behncke (2002) divides self-regulatory processes into different stages, namely, self-control, goal-setting and goal attainment, self-evaluation, selfimportance, self-efficiency, self-regulatory failure, etc. Knowing and understanding these processes can improve selfregulation and motivation. Zimmerman (2000) explains why we are able to selfregulate some actions, and not others. Unlike metacognitive approach to selfregulation which emphasizes the level of knowledge and deductive thinking when selecting a cognitive strategy, Zimmerman applies a social cognitive perspective and advises including the individuals' selfbeliefs and emotional responses, such as fear or doubt in the process.

\section{Triadic model of self-regulation}

Zimmerman (2000) introduces a triadic model of self-regulation, including the personal, behavioural and environmental domains. The model does not simply relate to knowledge, skills and self-management while trying to control elements of the environment, but also raises awareness of personal functioning while coping with the environment. 


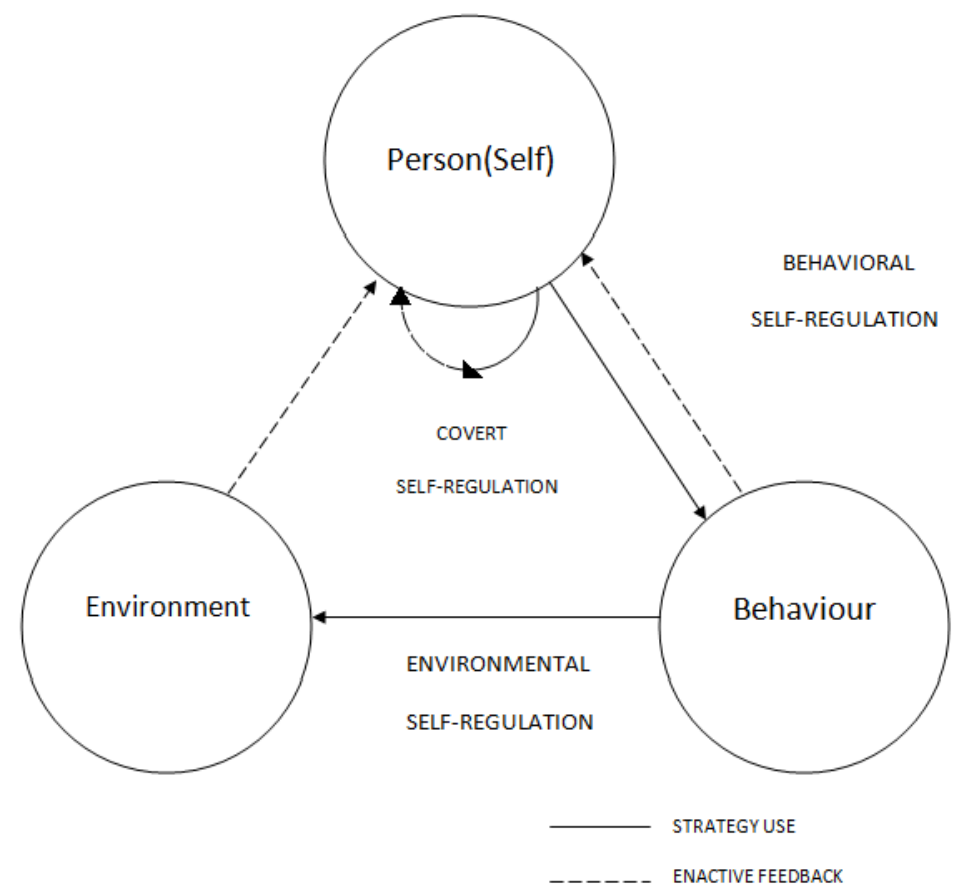

Figure 1: Triadic model of self-regulation (Clark \& Zimmerman, 2014).

As can be seen in Figure 1, the person acts in a selected setting and makes conclusions on his or her behaviour based on the consequences of his or her behaviour within the environment. The person can change subsequent behaviour according to the consequences of his or her behaviour. Zimmerman (1989) speaks of the selfregulation loop which begins by using different strategies and is sustained or modified based on active feedback. The author differs between self-regulatory processes, such as self-monitoring, and self-regulatory strategies, such as recordkeeping, which are meant to optimize selfregulatory processes.

\section{The structure of self-regulatory systems}

Zimmerman (2000) differs between efficient and inefficient self-regulation, where the quality of self-regulation depends on self-regulatory processes within the individual. We speak of three cyclical phases of self-regulation: forethought phase, performance phase and self-reflection.

Forethought phase includes two categories, namely task analysis and self-motivation beliefs. Task analysis demands an individual to set goals and plan the task strategically. In this phase, the learner fragments the task and establishes strategies. Self-motivational beliefs, which include variables that generate and maintain motivation for task performance, are self-efficacy, task value, interest, outcome expectation and goal orientation.

Performance phase consists of two key elements, which are self-observation and self-control. Self-observation refers to the individuals' ability to observe thought processes and emotional reactions, while self-control includes processes that can help focus, improve concentration and improve performance, such as selfinstruction, imagery, time management, help-seeking or task-strategies. 
Self-reflection also includes two processes, self-judgement and self-reaction. During the process of self-judgement the learner assesses his or her work, and finds reasons for success or failure. In the process of self-reaction, the individual reacts to selfjudgement in the form of cognitive and affective responses and considers performing the task in the future by activating learning strategies.

\section{Self-regulation of learning}

Research into learning strategies and their effect on academic success has shown that learners who were equipped with the knowledge of various learning strategies improved their learning achievements significantly (Radovan, 2010). Selfregulated learning is characterized by a systematic goal orientation. Students who self-regulate their learning are confident in their efficiency and abilities, and are intrinsically motivated to learn (Pintrich \& De Groot, 1990). Self-regulated students are often described as decisive, strategic and persistent; they are able to monitor their progress and are goal oriented (Doria, 2011).

Zimmerman, Bonner and Kovach (1996) suggest a model of self-regulatory learning, consisting of four stages:

(1) Self-evaluation and monitoring: the learner assesses his or her success based on previous results by making notes on the performance of the task or feedback from the teacher, parents or peers.

(2) Goal-setting and strategic planning: the learner analyses learning goals and plans improvements in existing learning strategies.

(3) Putting a plan into action and monitoring it: the learner applies known learning strategies to perform a task.
(4) Monitoring outcomes and refining strategies: the learner decides whether applied strategies were appropriate in relation to his or her results.

\section{The research}

Our research aimed at finding out how a group of elementary school students learns. More specifically, we were interested in which elements of self-regulation the students applied in the process of learning, whether they are familiar with their learning styles, which learning strategies they usually opt for, how they plan their learning, where and when they learn and whether they are able to reflect on their learning and find reasons for success or failure. The interviews with 9 students (5 boys, 4 girls), aged 14, took place in February 2017. We conducted individual semi-structured interviews where the participants were asked a series of questions imbedded in a conversation about their learning; their answers were recorded. After individual interviews, the students participated in a group discussion where we presented them with the idea of self-regulatory learning, learning strategies and learning styles.

\section{Results and interpretation}

When do you learn?

All of the students explained that they learn in the afternoon, with one adding she learns in the morning before school as well. In terms of planning their learning ahead of formal assessment (test, written exam, etc.), all of the students learn beforehand, however, 2 of them answered they learn at least a week ahead of the assessment, while 7 explained they learn the day or sometimes two before being assessed. 
In case of oral exams, all of the students answered they learn the afternoon before oral exams. None of the students answered they think about the time they will spend learning in terms of planning ahead.

Where do you learn?

All of the students answered they learn in their rooms, 5 of them on their bed and 4 sitting at their desks. Two of the students said they sometimes learn in the kitchen or in the living room because their parents want to see them learn. Most of the students prefer learning in a quiet environment. One of them likes to practice before exams with the help of his sister who asks him questions.

\section{Learning aids}

All of the students explained they learn from textbooks and the notes they write down during lessons. These notes are what the teacher tells them to write down. Only one of the students said she likes to make her own notes at home, including using charts, different colours, etc.

\section{Learning styles}

Eight of the students learn by silently reading from their textbooks, which points to verbal learning style. Three also answered they like to underline what they read in different colours or draw charts and sketches (visual learning style). One of the students explained he likes having his sister read from his textbook for him, which is typical of aural learning style.

\section{Motivation}

When asked what motivates them to learn, all of the student answered "grades". When asked what subjects they enjoy learning, one of the students answered she likes to learn Geography and History because she likes imagining about other places and times, and another student answered she likes learning English because it is her favourite subject. The rest of the students did not express any particular liking of individual subjects.

\section{Self-reflection}

All of the students answered they are happy when they study a lot and get a good grade. When asked how they feel when they do not study and get a bad grade, all of them feel bad or angry with the subject, the teacher, or themselves. When asked how they feel when they do study and still get a bad grade, all of them said they feel bad or angry with the teacher ("the test was too difficult").

\section{Conclusions}

In teaching practice, we can often notice that many students find great motivation in grades. On the other hand, we are faced with students who do not like to learn and are not motivated for schoolwork. Of course, there are those, who are curious about learning new things and are intrinsically motivated when it comes to learning. One thing all these students have in common is that they can improve their academic outcomes if they approach the learning process more systematically. This can happen only if the students think about the learning process, i.e. learn how to learn. One of the most important qualities of self-regulatory learning is a proactive view of learning as an individual-oriented approach in which the learner is able to transform cognitive abilities into academic skills (Lončarić \& Peklaj, 2008). However, not all children are able to understand this, which can be explained through metacognitive development. 
Namely, as children develop, they can approach learning more strategically and use more complex cognitive and metacognitive strategies (Pintrich \& Zusho, 2002), and self-regulate their learning more efficiently (Pressley \& Ghatala, 1990).

Exploring the learning habits of the students in the research exposes an absence of self-regulation, as the students do not approach learning systematically and rather see it as something they have to do before assessment. They do not distribute school tasks across their time and sometimes find themselves overwhelmed with the amount of things they have to do for school. We can imagine that affective responses in such situations additionally burden the students' well-being, bringing them in stressful situations. The students in the research tend not to think about their learning and see it as reproduction of facts they have memorized. On a more positive note, the students were interested in learning about their own learning styles and what works for them. We believe all students should be taught how to approach learning in practical ways in order to improve the quality of knowledge and motivation of the students by introducing them to the model of self-regulatory learning (Zimmerman, Bonner, \& Kovach, 1996). This requires the involvement and cooperation of the teachers who can demonstrate learning specific subjects using various strategies and approaches however, the teachers should cooperate and help the students realize that same strategies and approaches can be applied across a range of topics and subjects.

\section{References}

- Behncke, L. (2002). Self-regulation: A brief overview. Athletic Insight: The online journal of sport psychology, 14 (1), 313-325.

- Clark, N. M., \& Zimmerman, B.J. (2014). A Social Cognitive View of SelfRegulated Learning About Health. Health Education \& Behavior, 41(5), 485-491. DOI: $10.1177 / 1090198114547512$

DOI : http://dx.doi.org/10.1207/s15326985ep250 $1 \_3$

- Doria, J. (2011). Samoregulacija in učenje. Ljubljana: Atelje Doria.

- Lončarić, D., \& Peklaj, C. (2008). Proaktivna in defenzivna samoregulacija pri učenju. Psihološka obzorja, 17 (4), 73-88.

- $\quad$ Pintrich, P. R., \& de Groot, E. V. (1990). Motivational and self-regulated learning components of classroom academic performance. Journal of Educational Psychology, 82(1), 33-40. DOI: http://dx.doi.org/10.1037/0022$\underline{0663.82 .1 .33}$

- Pinrich, P. R., \& Zusho, A. (2002). The development of academic self-regulation: The role of cognitive and motivational factors. In A. Wigfield \& J. S. Eccles (Eds.), A Vol. in the educational psychology series. Development of achievement motivation (249-284). San Diego, CA, US: Academic Press. DOI: http://dx.doi.org/10.1016/B978-

012750053-9/50012-7

- Pressley, M., \& Ghatala, E. S. (1990). Self-regulated learning: Monitoring learning from text. Educational Psychologist, 25(1), 19-33.

- Radovan, M. (2010). Vpliv dejavnikov samoregulativnega učenja in starosti na uspešnost pri študiju. Sodobna pedagogika, 5, 94-115.

- Zimmerman, B. J. (2000). Attaining selfregulation: A social cognitive perspective. 
(JPMNT) Journal of Process Management - New Technologies, International

Vol. 6, No 4, 2018.

In M. Boekaerts, P. R. Pintrich, \& M.

Zeidner (Eds.), Handbook of selfregulation (13-39). San Diego, CA, US:

Academic Press. DOI:

http://dx.doi.org/10.1016/B978-

012109890-2/50031-7

- Zimmermann, B. J. (1989). A Social Cognitive View of Self-Regulated Academic Learning. Journal of Educational Psychology,81(3), 329-339.
DOI: $\quad$ http://dx.doi.org/10.1037/00220663.81.3.329

- Zimmerman, B. J., Bonner, S., \& Kovach, R. (1996). Psychology in the classroom: A series on applied educational psychology. Developing self-regulated learners: Beyond achievement to self-efficacy. Washington, DC, US: American Psychological Association. DOI: http://dx.doi.org/10.1037/10213-000 